\section{Effect of Sealant Application and Thermal Cycling on Bond Strength of Tissue Conditioners to Acrylic Resin}

Francisca Neta Cruz Soares Sampaio ${ }^{1}$, José Renato Ribeiro Pintoํㅜ, Cecilia

Pedroso Turssi², Roberta Tarkany Basting ${ }^{2}$

\author{
'Department of Dental \\ Rehabilitation, Dental School, São \\ Leopoldo Mandic Dental Research \\ Institute, Campinas, SP, Brazil \\ ${ }^{2}$ Department of Restorative \\ Dentistry, Dental School, São \\ Leopoldo Mandic Dental Research \\ Institute, Campinas, SP, Brazil
}

Correspondence: Profa. Dra. Roberta Tarkany Basting, Rua José Rocha Junqueira, 13, 13045-755 Campinas, SP, Brasil. Tel: +55-19-3211-3610. e-mail: rbasting@yahoo.com

\begin{abstract}
The aim of this study was to evaluate the effect of sealer application and thermal cycling on the bond strength between tissue conditioners and acrylic resin, and to observe the

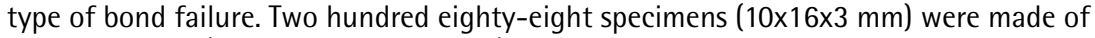
an acrylic resin (Lucitone 500, Dentsply) using a metal muffle. Specimens were divided into four groups according to the tissue conditioner (Coe-Comfort, GC or Dentusoft, Densell) used and whether or not a sealer (Eversoft Soft Liner Sealer, Myerson) was applied. Each of the four groups was subdivided into other six subgroups $(n=12)$ to undergo thermocycling for 45, 90, 135, 180 or 210 cycles with a dwell time of $60 \mathrm{~s}$, or to be left non thermocycled (control). Tensile bond strength was measured in a universal testing machine at a crosshead speed of $5 \mathrm{~mm} / \mathrm{min}$. Sealant application had no effect on the tensile bond strength of the relined acrylic resin, regardless of the tissue conditioner used (Coe-Comfort: $p=0.306$ and Dentusoft: $p=0.1501$ ). The number of thermal cycles had a significant effect on the tensile bond strength of the relined acrylic resin (Coe-Comfort: $p=0.002$ and Dentusoft: $p<0.001)$. Both tissue conditioners presented similar bond strength to acrylic resin. For both tissue conditioners, sealer coatings had no influence on bond strength, while different numbers of thermal cycles affected that mechanical property.
\end{abstract}

Key Words: acrylic resin, thermocycling, tissue conditioners, surface sealants.

\section{Introduction}

Acrylic resins used in complete dentures and removable partial dentures are rigid materials, and may not be tolerated by some patients due to the discomfort caused to the oral mucosa. This discomfort is particularly experienced by patients with xerostomia or those with resorbed alveolar ridges, sensitivity in the mental foramen region, dentures antagonized by natural teeth, congenital or acquired defects, or having undergone to oral cavity surgery, dental extractions, or implant placement surgery (1).

One approach of improving the stability and adaptation of dentures, and thereby providing comfort for patients relies on the use of tissue conditioning agents or reliners (2), which have viscoelastic features, absorb the impact energy of masticatory forces, and allow for a uniform force distribution on the supporting tissues (3). However, tissue conditioners undergo sorption, solubility, and temperature-induced changes in the oral cavity (3-7). As a result, dimensional alterations, distortion, stiffening, odor incorporation, microorganism retention, color change, and debonding from denture bases may occur $(7,8)$, thereby affecting negatively the efficacy of tissue conditioners.

In an attempt to overcome the aforementioned limitations, especially to reduce water sorption and loss of plasticity of tissue conditioners, researchers have proposed the application of ethyl ketone-based sealants, which would act as coating agents $(9,10)$. In fact, the use of such sealer coatings increases the durability, resilience, and longevity of tissue conditioners $(10,11)$. However, an important issue is whether in the intraoral conditions, such as under functional temperature fluctuations, surface sealants would still exert their potential protection.

Despite the fact that there have been studies on the bonding between tissue conditioners and denture bases $(3,12)$, to date there are few in which surface sealants and thermocycling of relined acrylic resins have been investigated $(10,13)$. Therefore, the aims of this study were to evaluate the effect of sealant application and thermocycling on the tensile bond strength of tissue conditioners to an acrylic resin, and to observe the type of bonding failure.

\section{Material and Methods}

\section{Experimental Design}

This investigation was set up as a completely randomized

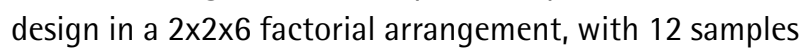
per treatment. The factors under study were: 1 . Tissue conditioner, at two levels: Coe-Comfort (CG; Alsip, USA) and Dentusoft (Densell; Buenos Aires, Argentina); 2. Application of Eversoft (Myerson; Chicago, IL, USA) sealant at two levels: present and absent (as control); and 3. Number of thermal cycles, at six levels: 0 (non thermocycling as the control), $45,90,135,180$, and 270 thermal cycles.

The experimental units consisted of 288 specimens 
fabricated from thermopolymerized acrylic resin Lucitone 550 (Dentsply; Santiago, Chile); half bonded to CoeComfort and the other half to Dentusoft. Both groups were randomly divided into subgroups to receive or not receive the sealant application (4 subgroups). Each of the four subgroups was further divided into six sub-subgroups according to the number of thermal cycles, thus totaling 24 groups containing 12 specimens each. The response variables were the tensile bond strength, measured in $\mathrm{MPa}$, and the mode of fracture, characterized as adhesive, cohesive, or mixed.

\section{Fabrication of Acrylic Resin Bars}

To allow the fabrication of the 288 thermo-polymerized acrylic resin specimens, which would be relined with the tissue conditioners, a custom-made metallic muffle 113.5 $\mathrm{cm}$ wide, $120.0 \mathrm{~cm}$ high, and $40.0 \mathrm{~cm}$ thick was built. This muffle consisted of five plates: one top plate, three central plates with six metal spacer bars and a bottom plate (Fig. 1). The purpose of the central plates was to provide and standardize the spaces for inserting the acrylic resin (Lucitone 550). The bottom plate was designed to stabilize the second and fourth plates, favoring the creation of a negative portion for fabricating the samples made of thermopolymerized acrylic resin (Lucitone 550), for later application of one of the tissue conditioner materials.

To standardize the space where the tissue conditioner materials were inserted, six vertical metal spacer bars were fabricated, measuring $70 \mathrm{~mm}$ long, $5 \mathrm{~mm}$ high, and $3 \mathrm{~mm}$ thick. The muffle allowed 24 specimens to be fabricated in each polymerization process. For closure and final stabilization of the muffle, a superior plate was used and fixed with two nuts, which were fastened onto the guide screws of the bottom plate, preventing any movement of the other muffle plates during the polymerization cycle and specimen fabrication process.

To fabricate the acrylic resin samples, the internal

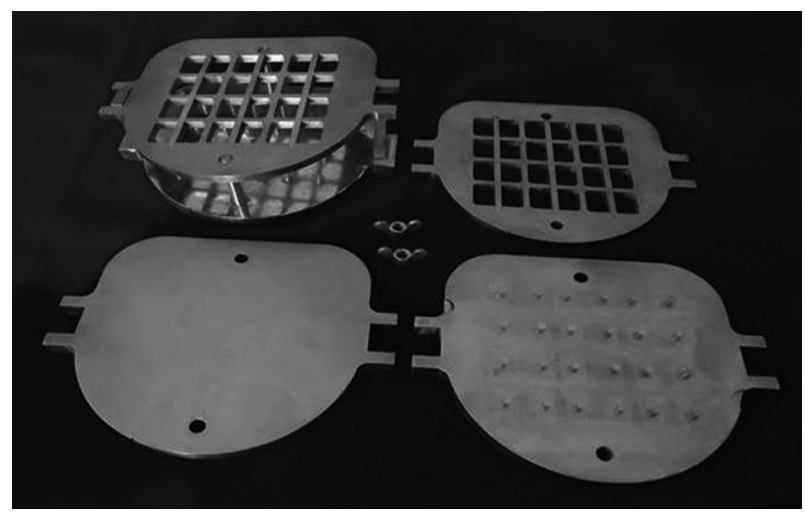

Figure 1. Custom-made muffle used to fabricate acrylic resin bars. surfaces of the five constituent plates of the muffle were duly isolated with solid petroleum jelly (Vipi, Pirassununga, $\mathrm{SP}$, Brazil) and acrylic resin isolator (Vipi). The resin was manipulated and inserted into the central plates of the muffle, and the remaining plates were put into place. The muffle was closed and submitted to slow pressing in a hydraulic bench press (Techno; Vinhedo, SP, Brazil) under a $1.25 \mathrm{t} \mathrm{load}$ for $10 \mathrm{~min}$.

The muffle was taken out of the press, opened, and the excess of acrylic resin was removed. Next, the muffle was closed and taken to the heat polymerizing unit (Termotron; São Paulo, SP, Brazil) to perform the polymerization cycle at $73^{\circ} \mathrm{C}$ for $90 \mathrm{~min}$, and then at $100^{\circ} \mathrm{C}$ for $30 \mathrm{~min}$. The muffle was then submerged under running water for $15 \mathrm{~min}$ and the acrylic resin samples were unmolded for later finishing in a rotary electric polisher (Arotec Ind. e Comércio; São Paulo, SP, Brazil) with abrasive paper (\#2000; 3M do Brasil Ltda.; Sumaré, SP, Brazil). Wear was controlled by means of a digital caliper (Mitutoyo Sul América Ltda.; Suzano, SP, Brazil) with a $0.01 \mathrm{~mm}$ accuracy, until the surfaces that would later come into contact with the tissue reliners attained the cross-sectional dimensions of $10 \times 5 \mathrm{~mm}$. The surfaces that would receive the tissue reliners were ground with an abrasive paper (\#2000; 3M do Brasil Ltda.) to allow uniformity of the bond surface of all the acrylic resin samples. Next, the specimens were stored in distilled water in a $37^{\circ} \mathrm{C}$ oven for $24 \mathrm{~h}$ (Odontobrás Ind. e Com. Equipamento Med. Odont. Ltda; Ribeirão Preto, SP, Brazil).

\section{Application of Tissue Reliners}

In order to completely fill the space dedicated to the tissue conditioners, the acrylic resin samples were carefully placed on the negative portions formed by the superimposition of the second and fourth plates on the bottom and third plates, without the spacer bars $(3 \mathrm{~mm}$ wide) (Fig. 2). The spaces were filled with either Coe-Comfort or Dentusoft, both of which manipulated according to the manufacturers' instructions. Next, the muffle was closed and placed in the hydraulic bench press under a $1.25 \mathrm{t}$

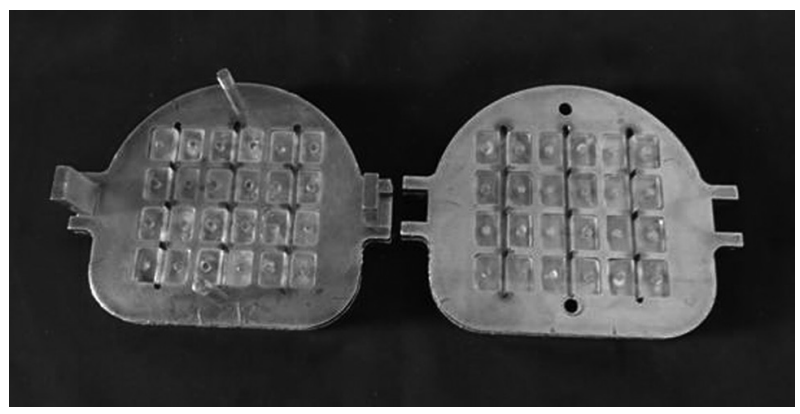

Figure 2. Acrylic resin bars repositioned in the muffle for application of the tissue conditioners. 
load. Specimens were carefully unmolded and the excess of tissue conditioner was removed by a \#15 scalpel blade (Solidor; Bauru, SP, Brazil), as shown in Figure 3.

\section{Surface Sealant Application}

Both groups, one relined with Coe-Comfort and the other with Dentusoft, were further divided into subgroups to receive or not the surface sealant, thus forming four subgroups. In the two subgroups in which the surface sealant Eversoft was applied, one coat of this product was air-dried for 1 min before application of a second coat. Control subgroups remained unsealed.

All subgroups remained stored in distilled water in a $37^{\circ} \mathrm{C}$ oven for $24 \mathrm{~h}$ (Odontobrás) until thermocycling was performed.

\section{Thermocycling of Specimens}

Thermocycling was performed in a thermal cycler appliance (MSCT-3 Plus; Marcelo Nucci - ME; São Carlos, $\mathrm{SP}$, Brazil) by alternating immersions of $60 \mathrm{~s}$ in distilled water at $5^{\circ} \mathrm{C} \pm 1^{\circ} \mathrm{C}$ and $60 \mathrm{~s}$ in distilled water at $55^{\circ} \mathrm{C} \pm 1^{\circ} \mathrm{C}$. According to the experimental sub-subgroups in which the specimens were placed, the specimens were thermocycled for $45,90,135,180$, or 270 cycles, which correspond to $15,30,45,60$, and 90 days of clinical usage (14). After thermocycling, specimens were dried with absorbent paper and submitted to the tensile bond strength test. Control subgroups remained non thermocycled.

\section{Tensile Bond Strength Test and Fracture Mode}

To perform the tensile bond strength test, a universal test machine (Emic DL-2000; São José dos Pinhais, PR, Brazil) with a load cell of $50 \mathrm{kgf}$ was used, at a constant speed of $5 \mathrm{~mm} / \mathrm{min}$. Specimens were placed in the machine with the top part adapted to the load cell of the equipment, so that the sample would remain perpendicular to the horizontal plane. Specimens were stressed in tension until rupture. Data were recorded in MPa.

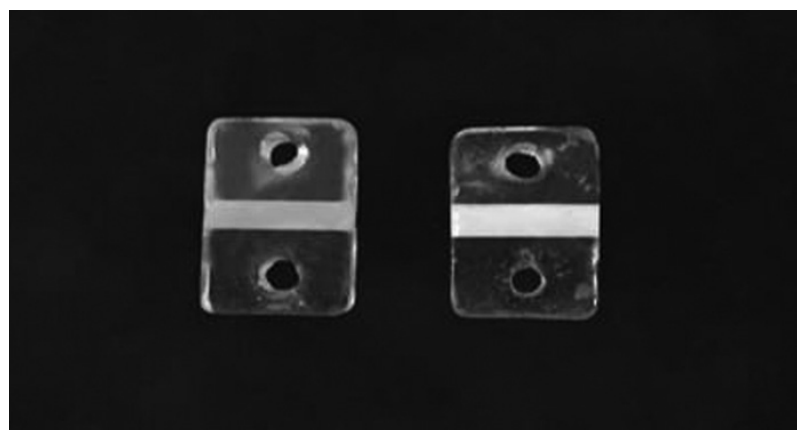

Figure 3. Close view of specimens after relining Coe-Comfort and the other with Dentusoft.
After the mechanical tests, the ruptured surfaces were observed under a stereomicroscope (Eikonal Equipamentos Ópticos e Analíticos; São Paulo, SP, Brazil) at 16x magnification. Failures were classified as adhesive (total debonding of the tissue reliner material from the acrylic resin), cohesive (total cohesive rupture of the tissue reliner), or mixed (occurrence of both types of ruptures).

\section{Statistical Analysis}

Tensile bond strength data were analyzed by three-way ANOVA and Tukey's test for pairwise multiple comparisons at $5 \%$ significance level.

\section{Results}

Three-way ANOVA showed a significant interaction among the factors under study $(p=0.019)$. For both reliners there were no significant interactions between the sealant application and the number of thermal cycles (Coe-Comfort: $p=0.285$ and Dentusoft: $p=0.076$ ). Sealant application had no effect on the tensile bond strength of the relined acrylic resin, regardless the used tissue conditioner (Coe-Comfort: $p=0.306$ and Dentusoft: $p=0.1501$ ). The number of thermal cycles had significant effect on the tensile bond strength of the relined acrylic resin (CoeComfort: $p=0.002$ and Dentusoft: $p<0.001$ ).

For the Coe-Comfort tissue conditioner, there was no difference in the tensile bond strengths between the groups thermocycled 45 and 90 times. When compared to these two groups, significantly higher values of tensile bond strength were observed in the specimens thermocycled 135, 180, and 270 times. The non-thermocycled specimens, however, did not differ from the thermocycled ones. For the conditioner Dentusoft, the highest tensile bond strength values were observed for the specimen groups thermocycled 0 and 270 times. No differences were noticed among the specimens thermocycled 45 and 90 times (Table 1).

Table 1. Tensile bond strength mean values for tissue conditioners in MPa (standard deviation) according to the number of thermal cycles

\begin{tabular}{ccc}
\hline Number of thermal cycles & Coe-Comfort & Dentusoft \\
\hline 0 & $0.25(0.09) \mathrm{ab}$ & $0.27(0.16) \mathrm{a}$ \\
45 & $0.22(0.11) \mathrm{b}$ & $0.20(0.14) \mathrm{ab}$ \\
90 & $0.18(0.09) \mathrm{b}$ & $0.17(0.12) \mathrm{ab}$ \\
135 & $0.29(0.14) \mathrm{a}$ & $0.13(0.10) \mathrm{b}$ \\
180 & $0.33(0.20) \mathrm{a}$ & $0.14(0.14) \mathrm{b}$ \\
270 & $0.27(0.11) \mathrm{a}$ & $0.26(0.15) \mathrm{a}$ \\
\hline
\end{tabular}

Means followed by different letters indicate statistically significant difference among the number of thermal cycles for each tissue conditioner. 
In general, there were no differences in the tensile bond strength values found for the specimens relined with Coe-Comfort and those with Dentusoft, as shown in Table 2. There were two exceptions for both conditioners: the sealed specimen groups thermocycled 135 times and the unsealed specimen groups thermocycled 180 times. In both thermal cycle times, Coe-Comfort showed higher tensile bond strength than Dentusoft.

As can be seen from Table 3, there was a predominance of cohesive failures among Coe-Comfort sealed specimens, regardless the number of thermal cycles. An exception was found in the specimens thermocycled 135 times, in which 50\% of the failures were cohesive and 50\% were adhesive. For the Coe-Comfort unsealed specimens, the ones non thermocycled showed a predominance of adhesive failures (60\%). On the other hand, except for those at 90 cycles, the thermocycled specimens showed a predominance of cohesive failures. The exceptions, the specimens thermocycled 90 times, had 45\% cohesive failures, $45 \%$ adhesive failures, and $10 \%$ mixed failures.

\begin{tabular}{|c|c|c|c|c|}
\hline \multirow{2}{*}{$\begin{array}{l}\text { Number } \\
\text { of thermal } \\
\text { cycles }\end{array}$} & \multicolumn{2}{|c|}{ Unsealed } & \multicolumn{2}{|c|}{ Sealed } \\
\hline & Coe-Comfort & Dentusoft & Coe-Comfort & Dentusoft \\
\hline 0 & $0.27(0.10) \mathrm{a}$ & $0.19(0.09) \mathrm{a}$ & $0.21(0.07) \mathrm{a}$ & $0.35(0.16) \mathrm{a}$ \\
\hline 45 & $0.22(0.08)$ a & $0.16(0.09) \mathrm{a}$ & $0.21(0.13) \mathrm{a}$ & $0.23(0.17) \mathrm{a}$ \\
\hline 90 & $0.19(0.11) \mathrm{a}$ & $0.15(0.10) \mathrm{a}$ & $0.16(0.07) \mathrm{a}$ & $0.17(0.14) \mathrm{a}$ \\
\hline 135 & $0.28(0.15) \mathrm{a}$ & $0.13(0.09) \mathrm{a}$ & $0.28(0.12) \mathrm{a}$ & $0.12(0.09) b$ \\
\hline 180 & $0.38(0.23) \mathrm{a}$ & $0.10(0.08) \mathrm{b}$ & $0.27(0.13) \mathrm{a}$ & $0.16(0.17) \mathrm{a}$ \\
\hline 270 & $0.23(0.10) \mathrm{a}$ & $0.28(0.16) \mathrm{a}$ & $0.30(0.11) \mathrm{a}$ & $0.22(0.13) \mathrm{a}$ \\
\hline
\end{tabular}

Means followed by different letters indicate statistically significant difference between the tissue conditioners within sealed and unsealed specimens.

Table 3. Frequency of fracture modes (in \%) for Coe-Comfort, according to sealant application and number of thermal cycles

\begin{tabular}{ccccccccc}
\hline \multirow{2}{*}{$\begin{array}{l}\text { Number } \\
\text { of thermal } \\
\text { cycles }\end{array}$} & \multicolumn{2}{c}{ Adhesive } & & \multicolumn{2}{c}{ Cohesive } & & \multicolumn{2}{c}{ Mixed } \\
\cline { 8 - 9 } \cline { 7 - 8 } \cline { 7 - 8 } & Sealed & Unsealed & & Sealed & Unsealed & & Sealed & Unsealed \\
\hline 0 & $30 \%$ & $60 \%$ & & $70 \%$ & $25 \%$ & & $0 \%$ & $15 \%$ \\
45 & $15 \%$ & $35 \%$ & & $70 \%$ & $50 \%$ & & $15 \%$ & $15 \%$ \\
90 & $25 \%$ & $45 \%$ & & $65 \%$ & $45 \%$ & & $10 \%$ & $10 \%$ \\
135 & $50 \%$ & $25 \%$ & & $50 \%$ & $65 \%$ & & $0 \%$ & $10 \%$ \\
180 & $15 \%$ & $10 \%$ & & $85 \%$ & $80 \%$ & & $0 \%$ & $10 \%$ \\
270 & $15 \%$ & $35 \%$ & & $80 \%$ & $65 \%$ & & $5 \%$ & $0 \%$ \\
\hline $\begin{array}{l}\text { Grand } \\
\text { mean }\end{array}$ & $25 \%$ & $35 \%$ & & $70 \%$ & $55 \%$ & & $5 \%$ & $10 \%$ \\
\hline
\end{tabular}

Dentusoft conditioner specimens, both sealed and unsealed, showed $100 \%$ cohesive failures.

\section{Discussion}

The main cause of failures in relined dentures is debonding between the relining materials and the denture base (4). Therefore, high tensile bond strength between acrylic resin and tissue conditioners is considered important, especially because rupture of this bond leads to biofilm accumulation (15). As debonding may be related to water sorption, solubility, and temperature-induced changes of relining materials (3-6), coating agents have been applied on the relining materials with the intent of extending their life (16). Nevertheless, the results of the present study showed that the surface sealant applied to both tissue conditioners had no influence on the tensile bond strength values, as no difference was observed between sealed and unsealed groups. A possible explanation for this may rely on the fact that the sealant integrity may have deteriorated over time or due to thermocycling. Such speculation can also substantiate the conflicting results between the current study and a previous investigation (10) in which the sealed Coe-Comfort specimens were shown to preserve their original hardness. However, a direct comparison between the quoted and current investigations cannot be made because of the different mechanical tests and research protocols used in the study. This is especially true because in the study by Mante et al. (10), specimens were immersed in artificial saliva, alcohol, and denture cleaner rather than thermocycled in water, but the use of a sealer played an important role in the preservation of the hardness of some resilient lining materials in their study.

Thermocycling was used with the intent of simulating the temperature fluctuations that occur in the oral cavity (17) to generate stress at the denture base/reliner interface, and to stiffen the reliner due to aging. In effect, the tensile bond strength of both reliners (Coe-Comfort and Dentusoft) was shown to be affected by the different number of thermal cycles. This agrees with the findings of a previous report (18). However, in comparison with the present study, a larger number of thermal cycles was used in the aforementioned research.

Although thermocycling had a significant effect on the tensile bond strength of tissue conditioners to acrylic resin, it is worth noting that under the chosen regimen no difference existed in the tensile bond strength values observed for 
specimens subjected to 270 thermal cycles and those not thermocycled. A possible explanation for this finding may be the low number of applied thermal cycles, however, due to the fact that non-thermocycled Dentusoft specimens differed from those thermocycled 135 and 180 times, chances are that the lack of difference between the tensile bond strength values found after 0 and 270 thermal cycles for both tissue conditioners may have occurred by chance.

Although the heat during thermocycling has been described as causing rupture of molecular bonds in polymers, which could reduce the bond strength between tissue conditioners and the denture base (19), other aspects may have a more significant effect on tensile bond strength Loss of plasticizer from tissue conditioners, their ethanol concentration, and elution over time can render tissue conditioners stiffer and transmit the external loads to the bond site, reducing tensile bond strength (17). In effect, it has been demonstrated that thermocycling does not necessarily influence the tensile bond strength of relining materials (17).

When the bond strength values of the two tissue conditioners were compared, it was observed that CoeComfort presented a higher strength than Dentusoft after 135 and 180 thermal cycles under sealed and unsealed conditions, respectively. However, overall, both tissue conditioners performed similarly regarding tensile bond strength.

Dentusoft presented cohesive failures, both for thermocycled and non-thermocycled specimens, showing that the bond at the interface is higher than within the material $(8,20)$. For Coe-Comfort, the failures in the sealed non-thermocycled specimens were $70 \%$ cohesive and 30\% adhesive, whereas in the unsealed specimens the failures were $60 \%$ adhesive, $15 \%$ mixed, and 25\% cohesive. The sealant probably protected the bond between Coe-Comfort and the acrylic resin, as fewer adhesive failures were noticed in the sealed groups. For those specimens sealed and thermocycled 45 times, there were $70 \%$ cohesive, 15\% adhesive, and 15\% mixed failures, whereas for the unsealed specimens there were $50 \%$ cohesive failures, $35 \%$ adhesive, and 15\% mixed. This indicates that the sealant influenced the type of failure. After 90 thermal cycles, the sealed group showed cohesive failures in 65\% of the specimens, adhesive failures in $25 \%$, and mixed failures in 10\%, whereas the unsealed group presented $45 \%$ cohesive failures, $45 \%$ adhesive, and $10 \%$ mixed. This shows that the sealant did not protect the Coe-Comfort bond to acrylic resin. For the sealed group undergoing 135 thermal cycles, 50\% of failures were cohesive and $50 \%$ adhesive, whereas the unsealed group presented $65 \%$ cohesive failures, 25\% adhesive, and 10\% mixed. This again substantiates that the sealant cannot exert any protection for the tissue conditioner Coe-Comfort. After 180 and 270 thermal cycles, sealed and unsealed samples showed cohesive, adhesive, and mixed failures. In summary, the large majority of failures were cohesive, demonstrating that the cohesive strength of the tissue conditioners was not satisfactory, as the sealant promoted minimal interference on the type of failure. This is probably due to the fact that this material is acrylic resin-based and, consequently, releases plasticizing components, causing a partial loss of resistance and an increase in stiffness (21). This, together with the effect of water penetration at the interface of acrylic resin, can result in a weak bond (22). For Dentusoft, 100\% of the failures were cohesive, which was probably due to the existence of a cohesive force between the molecules lower than the tensile bond strength of this material (23). However, this probable protection provided by the sealant has not shown to have an effect on the tensile bond strength of the tissue conditioners.

In general, based on the potential temperatureinduced changes caused by thermocycling and on previous literature data on the properties of tissue conditioners, it seems reasonable to follow the recommendation of using such materials no longer than two weeks $(24,25)$. In situ and in vivo studies are required to elucidate whether the current findings on the effects of sealant application and temperature fluctuations hold for clinical situations.

It may be concluded that the Coe-Comfort and Dentusoft tissue conditioners presented similar bond strength to acrylic resin. For both tissue conditioners, sealer coatings had no influence on bond strength, while different numbers of thermal cycles affected this mechanical property.

\section{Resumo}

Os objetivos deste estudo foram avaliar o efeito da aplicação de selante e a ciclagem térmica na resistência de união entre condicionadores de tecido e resina acrílica e observar o padrão de fratura. Duzentos e oitenta e oito espécimes (10x16×3 mm) de resina acrilica (Lucitone 500, Dentsply) foram confeccionados utilizando-se uma mufla metálica. Os espécimens foram divididos em quatro grupos de acordo com o condicionador de tecido (CoeComfort, GC ou Dentusoft, Densell) e com o uso ou não de selante (Eversoft Soft Liner Sealer, Myerson). Cada um dos quatro grupos foi subdividido em seis grupos para a realização de 45,90, 135, 180 ou 210 ciclos térmicos, ou ausência de termociclagem (controle). Resistência de união por tração foi mensurada em uma máquina universal de ensaios com velocidade de $5 \mathrm{~mm} /$ min. A aplicação de selante não afetou a resistência de união por tração da resina acrílica reembasada, independentemente do condicionador de tecido utilizado (Coe-Comfort: $p=0,306$ e Dentusoft: $p=0,1501$ ). 0 número de ciclos térmicos apresentou efeito significativo na resistência de união por tração da resina acrilica reembasada (Coe-Comfort: $p=0,002$ e Dentusoft: $p<0,001)$. Ambos os condicionadores de tecidos apresentaram resistência de união semelhante à resina acrílica. Para ambos os condicionadores de tecidos, a aplicação de selante não apresentou influência na resistência de união, enquanto que diferentes números de ciclos térmicos afetaram essa propriedade mecânica.

\section{References}

1. Brown D. Resilient soft liners and tissue conditioners. $\mathrm{Br}$ Dent J 
1988; $164: 357-360$

2. Machado C, Sanchez E, Azer SS, Uribe JM. Comparative study of the tranverse strength of three denture base materials. J Dent 2007;3:930933.

3. Mese A, Guzel KG. Effect of storage duration on the hardness and tensile bond strength of silicone - and acrylic resin-based resilient denture liners to a processed denture base acrylic resin. J Prosthet Dent 2008;99:153-159.

4. Kawano F, Dootz ER, Koran A 3rd, Craig RG. Comparison of bond strength of six soft denture liners to denture base resin. J Prosthet Dent 1992;68:368-371.

5. Handa RK, Jagger DC, Vowles RW. Denture cleansers, soft lining materials and water temperature:what is the effect? Prime Dent Care 2008;15:53-58.

6. Jorge JH, Giampaolo ET, Vergani CE, Pavarina $\mathrm{AC}$, Machado $\mathrm{AL}$, Carlos IZ. Effect of microwave postpolymerization treatment and of storage time in water of the cytotoxicity of denture base and reline acrylic resins. Quintessence Int 2009;40:41-48.

7. Kimoto S, Kimoto K, Murakami H, Gunji A, Ito N, Kawai Y. Survival analysis of mandibular complete dentures with acrylic-based resilient liners. Gerodontology 2012 [Epub ahead of print. DOI: 10.1111/j.17412358.2012.00658.x].

8. Yanikoglu N, Denizoglu S. The effect of different solutions on the bond strength of soft lining materials to acrylic resin. Dent Mater 2006;25:39-44.

9. McCabe JF, Carrick TE, Kamohara H. Adhesive bond strength and compliance for denture soft lining materials. Biomaterials 2002;23:1347-1352.

10. Mante FK, Mante MO, Petropolous VC. In vitro changes in hardness of sealed resilient lining materials on immersion in various fluids. J Prosthodont 2008;17:384-391.

11. Hatamleh MM, Maryan CJ, Silikas N, Watts DC. Effect of net fiber reinforcement surface treatment on soft denture liner retention and longevity. J Prosthodont 2010;19:258-262.

12. Zhang $\mathrm{H}$, Fang J, Hu Z, Ma J, Han Y, Bian J. Effect of oxygen plasma treatment on the bonding of a soft liner to an acrylic resin denture material. Dent Mater J 2010;29:398-402.

13. Munksgaard EC. Leaching of plasticizers from temporary denture soft lining materials. Eur J Oral Sci 2004;112:101-104.

14. Anil N, Hekimoglu C, Buyukbas N, Ercan MT. Microleakage study of various soft denture liners by autoradiography: Effect of accelerated aging. J Prosthet Dent 2000;84:394-399.

15. Radford DR, Watson TF, Walter JD, Challacombe SJ. The effects of surface machining on heat cured acrylic resin and two soft denture base materials: a scanning electron microscope and confocal microscope evaluation. J Prosthet Dent 1997;78:200-208.

16. Hayakawa I, Takahashi Y, Morizawa M, Kobayashi S, Nagao M. The effect of fluorinated copolymer coating agent on tissue conditioners. Int J Prosthodont 1997;10:44-48.

17. Kulak-Ozkan Y, Sertgoz A, Gedick H. Effect of thermocycling on tensile bond of six silicone-based, resilient denture liners. J Prosthet Dent 2003;89:303-310.

18. Park SK, Lee YK, Lim BS, Kim CW. Changes in properties of short-termuse soft liners after thermocycling. J Oral Rehab 2004,31:717-724.

19. Qudah S, Hugget R, Harrison A. The effect of thermocycling on the hardness of soft lining materials. Quintessence Int 1991;22:575-580.

20. Murata $\mathrm{H}$, Hamada $\mathrm{T}$, Harshini $\mathrm{S}$, Toki $\mathrm{K}$, Nikawa $\mathrm{H}$. Effect of addition of ethyl alcohol on gelation and viscoelasticity of tissue conditioners. J Oral Rehabil 2001;28:48-54.

21. Gronet PM, Driscoll CF, Hondrum SO. Resiliency of surface-sealed temporary soft denture liners. J Prosthet Dent 1997;77:370-374.

22. Polyzois GL. Adhesion properties of resilient lining materials bonded to light-cured denture resins. J Prosthet Dent 1992;68:854-858.

23. Amin WM, Fletcher AM, Ritchie GM. The nature of the interface between polymethyl methacrylate denture base materials and soft lining materials. J Dent 1981;9:336-346.

24. Newsome PR, Basker RM, Bergman B, Glantz PO. The softness and initial flow of temporary soft lining materials. Acta Odontol Scand 1988;46:9-17.

25. Tay LY, Herrera DR, Quishida CC, Carlos IZ, Jorge JH. Effect of water storage and heat on the cytotoxicity of soft liners. Gerodontology 2012;29:e275-e280. 